\title{
The Complications of Kurdish Independence
}

\author{
Albertus Jacobus Meintjes \\ Cape Town, South Africa \\ Email: aj.meintjes@gmail.com
}

How to cite this paper: Meintjes, A. J. (2018). The Complications of Kurdish Independence. Open Journal of Political Science, $8,1-11$.

https://doi.org/10.4236/ojps.2018.81001

Received: October 11, 2017

Accepted: November 28, 2017

Published: December 1, 2017

Copyright (c) 2018 by author and Scientific Research Publishing Inc. This work is licensed under the Creative Commons Attribution International License (CC BY 4.0).

http://creativecommons.org/licenses/by/4.0/

\section{(c) (i) Open Access}

\begin{abstract}
The Middle East is a constant source of security and diplomatic related issues that are made complex by the heterogeneous background of its people, with states such as Iraq home to a mixed variety of people from different cultural and religious backgrounds. The Kurdish people are one such group, with a storied history of strife. Most recently a referendum in Iraqi Kurdistan has opened the topic of separation and the formation of a Kurdish state. This paper briefly examines the problems surrounding such a move, looking at the Kurdish region and its neighbours as well as possibilities for the future, referencing a wide range of news sources typically unused by the academic community.
\end{abstract}

\section{Keywords}

Kurdistan, Iraq, Daesh, International Studies, Independence

\section{The Complications of Kurdish Independence}

With the disastrous Daesh invasion of 2014 nearly defeated as Iraqi forces prepare to assault the final two bastions of Daesh resistance, Rawa and Al-Qa'im, Iraq as a strategic regional player becomes a focus. However, the issue of Kurdish independence is a major complication that has the potential to spark yet another conflict in the already embattled and devastated region. Kurdistan, the autonomous northern province of Iraq, recently held a referendum that ended in a massive majority vote for separation from the Iraqi state (Rudaw, 2017a). The Kurdish people have a long storied history seeking independence that stretches back to the early $20^{\text {th }}$ century, where pro-freedom sentiment existed under British rule in previously held areas of the Ottoman Empire. In Iraq, a pro-freedom movement has existed since the 60's which establishes that Kurds have long sought independence, and the move towards independence now involves the Peshmerga and a united Kurdish population. The separatist sentiment, however, 
hosts many problems in its own right, and a stern political and economic reaction has been taken against them by the Iraqi government.

As of the $16^{\text {th }}$ of October, Iraqi forces launched a large military operation to retake lands held by the Peshmerga and currently hold Kirkuk (Muñoz, 2017), further complicating the scenario. As such, this paper seeks to examine the current issue of Kurdistan, and look at the different outcomes that may occur. The significance of the conclusion will outline not only how separatist sentiment is shaped, but also how regional powers are forming alliances in a post Daesh Middle East, and how western support is highly uncertain in this new environs.

In order to do this, the paper will first briefly examine the history of the Kurds to better understand the popular sentiment and gauge the drive of politicians in Kurdistan. This section will also delve into Kurdistan in the present, and examine the resources that the state has access to in the face of a drawn out economic, political or military crisis. Thereafter the paper will examine why the Iraqi state is against allowing Kurdish independence, and the actions they have taken so far, and are poised to take in the future. Thirdly, the paper will look at the international reaction, of both regional powers as well as overseas actors, what actions the regional actors have taken, as well as the sentiment that is being shared by more remote actors such as the US and Russia. Finally, the paper will use this information to look at three separate possibilities for Kurdistan in the future: Military conflict, a separate diplomatic solution or Kurdish independence, before making a final conclusion.

\section{Kurdistan: History}

The history of Kurdish oppression in the $20^{\text {th }}$ century dates back to the treaty of Lausanne. In the wake of World War One, the Ottoman Empire was able to annex Eastern Anatolia, an annexation allied forces had to accept in order to continue the peace process (HRI, 2017). In Northern Iraq, Kurdish minority have a long history of autonomous negotiations, after expected negotiations fell through in the 60 's, the Kurds revolted and ultimately expelled Iraqi military forces before the Abdul Salam Arif declared a ceasefire in 1963. Following internal strife in Iraq and the Ba'athist coup of 1968, autonomous negotiations were held again in 1970, but again failed to have any real effect, as the single party in Baghdad installed a Kurdish government themselves. Thus, Kurds had no real political autonomy. By the mid 70's, Saddam Hussein's Baath party oppressed and expelled Kurds, resulting in an insurrection during the Iran-Iraq war and the Al-Anfal campaign, which involved targeting of Kurdish civilians and the use of chemical weapons (Rutgers, 2017).

While the above is only a very brief snapshot of how Kurds suffered over the years, the purpose was to construct the rationale behind Kurdish sentiment for separation and formation of a Kurdish state. In 1991 the Iraqi military pulled out of Kurdistan following the end of the Gulf War, and Kurdistan became a de facto separate state. This however is still not the final objective of Kurdish decision 
makers, as the dream of a unified and separate Kurdish state is the next step. In recent years tensions between Kurdistan and Iraq have been building up. While there have been no overt moves towards independence, following US withdrawal in 2012 the Iraqi government demanded full control of the Peshmerga which was denied (Francis \& Al-Tamimi, 2017). In 2014, the chaos following the Iraqi crisis and the invasion of Daesh militants, the cohesive Kurdish forces were able to take and secure area from Daesh attacks in the Kirkuk governate while the Iraqi forces were broken during the initial invasion. These gains can be seen as the Kurds slowing moving in and holding territory to use either as a bargaining chip for future negotiations, or to hold on to the territories for future negotiations. Since then, Kurdish politicians have discussed the possibility of a referendum and in the present day, following the Peshmerga's assistance to US forces during the 2003 invasion of Iraq as well as the Peshmerga fighting Daesh in Northern Iraq and a weakened Iraqi state, Kurdistan now seeks to separate itself fully from Iraq and become an autonomous state.

\section{Kurdistan: Resources}

The Northern provinces of Iraq, the Dohuk, Erbil and Sulaymaniah governates form the Kurdistan region, and areas within those governates have seen large devastation since the Iraqi army's Al-Anfal campaign in the 80's. While the area has slowly been reconstructed over time, there is still a great deal of damage in the area. This section aims to examine the economic potential of these regions and look at the resources available in disputed territory between the Kurds and Iraqi government, such as Kirkuk, which is currently held by Kurdish forces. Kurdistan's resources can be split into Economic and Military.

Economically, the Kurdish government will need to consider not only natural resources and industry for trade, but basics of urbanisation such as water supply and power. In terms of power generation, Kurdistan holds natural gas stations of Erbil and Duhok, which combined produce roughly 2000 MW of electricity. Kurdish forces also currently hold the Kirkuk governate, where the Taza and Mulla Abdulla plants can produce just over $500 \mathrm{MW}$. This is fairly little for such a wide space of territory and holds little excess for expansion. It would take years to construct a new power station in the event of Kurdish independence, meaning that power would need to be bought from connections in the south, or load shedding would need to be implemented. Even is Kurdistan were to separate cleanly with the lands and infrastructure in tow, there would be need for power. However, the Iraqi military currently hold Kirkuk, and has moved into strategic areas in the Erbil and Sulaymaniah governates.

Alongside power, water is also a crucial resource. The water in Kurdistan is poorly managed and the majority of water is drawn from the five rivers in the region. The Sirwan and Zei originate from Iran, while the greater Zab and Khabur flow from Turki. The final river, the Awa Spi, is located entirely in Kurdis$\tan$. Zei Gawre, or Greater Zab, and the Khabur flow from Turkey. The fifth riv- 
er is the Awa Spi, which is located entirely in Kurdistan, while the remaining water that is required is drawn from groundwater supplies (Lynch, 2017). Should rivers be redirected from neighbouring states, which is a concern for rivers originating in Iran, there has been little work by Kurdish authorities to improve the water infrastructure in the region.

When speaking of natural resources in Iraq, the topic inevitably is drawn towards oil deposits, and Kurdistan is no different. With several wells already being exploited, in 2007, Kurdish authorities petitioned foreign companies to further invest in oil production in Kurdish held regions, sparking the ire of Iraqi government, who fear foreign companies will take over oil deposits throughout Iraq (Howard, 2017). Beyond oil, the Kurdistan region does have deposits of iron, gold, copper, zinc, nickel, iron, platinum and chromium (KRG, 2017). However, they have little or no exploitation, and are worthless without substantial investment.

In terms of logistical infrastructure, the Kurdistan region shares a land border with Turkey and Iran and has two airports, one in Erbil and one in Sulaymaniah, which have capacity for international flights and have operated flights around the Middle East and Europe. However, the political issues related to transport infrastructure are numerous, and will be dealt with in a later section. The road network is also somewhat limited with only a few border crossings, and rural roads being prevalent in some areas. While the above problems are only a small part of what it takes to run a successful state, bypassing other critical issues such as communication infrastructure including internet lines, the problems relating to economy are clear, and will be further fleshed out when examining how other states may react to a real move for Kurdish separation.

Militarily, the Kurds have the large Peshmerga forces. The Peshmerga are a unique military unit that have manpower of roughly 200,000 (Rudaw, 2017f). In terms of equipment, the Peshmerga forces have a wide variety of arms from various states, small arms from the US and NATO countries, as well as weapons from Russia. Many light vehicles are also fielded by Peshmerga forces including Humvees, technicals as well as APCs. While Peshmerga forces do have a stock of MANPADS, they only have a limited capacity to field rotary-wing air force, and rely on coalition or Iraqi air force to provide air cover. In addition, Peshmerga forces also have limited artillery capacity with mortars and howitzers, as well as anti-aircraft vehicles. The Peshmerga field a variety of tanks, mostly the outdated T-55 and more modern T-72, looted from Saddam Hussein's forces. However, their logistical capacity to field heavy weapons for extended operations is extremely limited (Berman, 2017). For such a small state, the Peshmerga are well equipped, thanks mainly to recovered enemy vehicles, munitions and relying on US and even Russian weapon shipments (Litovkin, 2017). US arms shipments have been regular since the 2014 Daesh invasion, together with limited support from Iran. However, US support has been limited in the type of weapons sent, for fear of arming the Kurds for an eventual move towards independence, a situation that ultimately proved true (Berman, 2017). 
However, the major issue with the Kurdish military force is that it lacks any real unified centralised leadership, and is split between forces loyal to the PUK and the KDP. Kurdistan as faced intra-state conflict before, and the failure of a political solution to control Peshmerga forces greatly weakens strategic command and control. While the Kurdistan region can field enough forces to hold their own and defend their borders, a protracted engagement would fail, particularly against a coalition. The lack of logistical capacity and supply together with political uncertainty would render the Peshmerga unable to defend themselves against a well organised opponent. While the lack of central political will could be damaging, the recent military actions of the Iraqi government will likely band Peshmerga leaders together with a common goal of defending Kurdish lands.

\section{Iraqi Sentiment and Actions}

The Iraqi government has rejected all overtures of separation talks, and has refused to recognise the validity of the referendum, despite Kurdish politicians stating the referendum was a springboard for negotiations, rather than a final decision. The most obvious reason the Iraqi parliament is set against Kurdish independence is the fracturing of the already shaky Iraqi state, whose problems are not only endemic of Daesh, but also tribal and sectarian conflict, would greatly strain the political situation in Baghdad, as well as with regional powers.

Kurdistan held traditionally disputed lands, such as the Kirkuk governate, and the Peshmerga forces controlling the area, it may well have been a major catalyst for why Kurdish authorities were hesitant to move the referendum up, despite the request of the US through a meeting with the US defence secretary in August (Gordon, 2017), in fear of losing momentum. It would seem the rationale was between losing valuable land and a fear of a destabilized political situation, a fear that ultimately proved true as the lands were seen as a catalyst for Iraqi military action and Kirkuk was taken from Peshmerga forces.

The actions that the Iraqi government took prior to military action were political in nature, seeming to focus on isolating Kurdistan, although there have been moves to reduce the economic capacity of the autonomous region. As stated earlier, immediately following the vote, the Iraqi parliament declared it unconstitutional (Al Jazeera, 2017). Soon after, a deadline on the routing of flights to Erbil and Sulaymaniah airports was established, with both airports currently not having any flights (Lee, 2017). This latter action puts strain on the already fragile Kurdish economy, and cuts easy access to Kurdistan for foreign employees and companies, isolating the state from courting further international investment. Most recently, the Iraqi government has requested that Turkey and Iran deal directly with Baghdad, rather than communicate with Kurdish authorities since early October 2017, further evidence of isolation as the primary strategy of the Iraqi government (Tasnim News Agency, 2017). However, Iraqi government may have been cooperating with regional powers to not only isolate Iraq, but also to secure the territories that Peshmerga forces secured in 2014 in 
the Kirkuk governate. Evidence for this can be found in the recent incidence on the $20^{\text {th }}$ of October 2017, where Iranian led militia were raised in Kirkuk to allegedly defend oil wells (The Baghdad Post, 2017). Further Iraqi military action in Kirkuk and other previously Kurdish held territory validates this theory.

PMF forces are crucial to the Iraqi strategic plan while fighting Daesh and sweeping areas. They are irregular forces that are not a single branch, but made up of roughly 20 separate militia groups, all following different leaders, with different goals and objectives. While central command can be traced back to PM Abadi who is the supreme commander of armed forces in Iraq, other controversial figure heads and leaders are at the head of the individual forces, such as Muqtada Al-Sadr for the infamous peace companies and Hadi Al-Amari for the majority Shiite Badr organisation. With such a structure, it isn't hard to envision some clashes and tension between Peshmerga forces and PMF elements. PMF forces were also formed specifically to combat Daesh, and with the end of major combat operations in sight with the liberation of Hawija and the final bastion of Al-Qa'im next, the future of the PMF is uncertain. PMF action in the Kirkuk governate has led to some major issues pertaining to looting and human rights violations in areas such as Tuz Khurmatu (Renaud, 2017), resulting in Abadi replacing PMF forces with Iraqi army (Rudaw, 2017g). However, not all PMF are interested in conflict as some are outspoken on a diplomatic solution, such as Al-Amari, who has stated that civil war must be avoided, and dialogue is the only option (Rudaw, 2017e).

The future of Iraqi action is uncertain. If following a policy of isolation, limiting access to Kurdistan via land routes through Southern Iraq, especially in tandem with Turkey and Iran, will do much to limit the movement of Kurds. Likewise, cutting off power connections or telecommunications as well as refusing to deal with Kurdish officials will make it near impossible for Kurds to take any real action, forcing either compliance or more serious action.

\section{International Actors}

The Kurdish people would likely need some sort of international backing to support their drive for independence. However, the international reaction to the Kurdish referendum has been mostly centred on invalidating the Kurdish position. The first to be examined here, Turkey, has a particularly chaotic history with the Kurdish people, as discussed in the history section, and will likely fear a separate Kurdish state as a catalyst for further uprisings and instability in its own state. The greater Kurdistan region claims areas in both Turkey and Iran, and a legitimate Kurdish authority would legitimise claims and diplomatic dialogue for the land based on the background of population groups in the region.

As such, the Turkish response to the referendum has been strong. Immediately following the referendum, Turkey denied its validity (Rudaw, 2017c) and began military exercise along the border with Iraqi forces in order to control the border as well as entry and exit points (Rudaw, 2017d). Most recently, Turkey 
has begun talks with Iraqi authorities to open a second border crossing towards the south in order to bypass Kurdistan entirely (Razzak, 2017). While previous years had seen some cooperation between the Turkish government and Kurdish authorities, such as flight route agreements, this was only under an understanding that the Kurds would remain a part of an Iraqi government. Together with blocking movement and military posturing, Turkey has also threatened to shut down the Cihan pipeline, a major source of income for the Kurdistan region, although Russia may well block the move, as shutting down the supply of oil would be "nobody's interest" (Rudaw, 2017b). Current posturing of Turkey has sent a clear message: Turkey will not accept an independent Kurdistan, and will take steps to ensure it does not come to fruition.

Opposite Turkey to the east lies Iran, another neighbour that has a long history with the Kurds. A more enigmatic state, Iran traditionally supported Kurdish forces as they moved against the Iraqi government in the days of Saddam Hussein. However, Iran has shifted their position since then, having been involved in military exercises along the border with Turkey and Iraqi forces, since the establishment of a federal Iraqi state. It seems unlikely they will support Kurdistan, favouring Iraq as a more powerful regional ally. As such, in recent months, Iran has been currying favour with Iraq, which it sees as an upcoming regional ally to use as a buffer against hostile Gulf States such as Saudi Arabia, who is also courting favour with Iraq. Cooperation between inter-state industries, particularly in the mineral sector (Al Ghad, 2017), and a military cooperation MOU have been signed (Reuters, 2017) that shows closer diplomatic ties with the Iraqi state. After the referendum took place, Iran shut down the Kurdistan 24 news centre in Tehran, citing developments in the Kurdistan region as a rationale behind the decision (Dolamari, 2017). Thereafter, a fuel embargo was placed on all fuel products moving in and out of Kurdistan, further straining Kurdish economic resources (Middle East Online, 2017). As stated earlier, Iran holds a part of what could be considered "greater Kurdistan", and likely fears a separation of northern Iraq will spark of similar calls in Iran, a similar fear that turkey shares. Unless Iran can gain greater political ground with an independent Kurdistan, assisting the Kurds seems highly unlikely.

Internationally, states have refused to recognise the validity of the referendum. The US has made its stance clear and support for the Kurds is simply not materialising, and without any international support, or at least domestic support within states overseas, the Kurdish position is very difficult. Before the referendum, US diplomatic efforts by Mattis to postpone the referendum was rejected, the Kurds citing that the referendum but remain fixed (Javanmardi, 2017). Ali Javanmardi, writing from the Kurdish perspective, found the Kurds and the US to be kindred spirits, the Kurds seeking independence and providing near constant military support for the US through the years. With Iraq establish closer ties with Iraq, the US interests must stay aligned with Iraq as far as possible (Javanmardi, 2017). However, the situation is complicated, as Kurdish fighters in Syria remain an ally for US interests, both against Daesh and a potential 
anti Syrian force, President Bashir being seen as a major problem in the region.

The only state to formally lend a supportive voice to the Kurds is Israel (Heller, 2017). However, the motivation for Israeli action is up for debate. Israeli support for the Kurds could be based on a similar historical background of oppression seeking a homeland, or support for a destabilised middle east, ensuring a fractured regional situation to avoid alliances against the Jewish state and maintain a buffer against Arab hostility against the Jewish state. No real material or concrete action has been taken other than diplomatic posturing, and Israeli support will likely now remain in the diplomatic sector without some major developments in the region.

The only non-state organisation to lend a voice to the Kurdistan issue has been the UN. Initially focusing on the sovereignty of Iraq and the need for cohesion following the Daesh crisis, the Iraqi states sudden military action forgoing a diplomatic solution, has earned condemnation of the Iraqi state (Renaud, 2017). With no real end in sight for Kurdish persecution, this is unlikely to be the end of growing international focus on Kurdistan.

\section{Possibilities}

Using the above information, it is possible to look at 3 possibilities for the future of the Kurdish people. Military action is the first and most worrying result of the Kurdish crisis, and has already occurred in several instances in Northern Iraq. Clashes between Peshmerga and Iraqi forces have occurred in the Kirkuk governate, Rubai border crossing (Mostafa, 2017) and Erbil governate. An examination of the Peshmerga reveals a lack of arms supplies in recent months, from the US cutting stipends and shipments (Detsch, 2017). Peshmerga forces have shown great ability in the past, but Peshmerga forces have been consistently withdrawing and avoiding prolonged engagements. Barring a political solution, an increasingly desperate Kurdish people may well continue to fight against the aggressive posture of the Iraqi federal government to secure a position, particularly if a fractured Peshmerga force and Kurdish militia is united by a singular goal.

A diplomatic solution is still likely following military action, as groups now seek to posture themselves for the upper hand during any future talks. Kurdish authorities have previously stated that the referendum was only a means to open a dialogue about separation, rather than a formal declaration of separation, pointing to the likelihood of driving for a diplomatic victory. However, the Iraqi position of isolation will quickly dry up economic sources for the Kurdistan region, ultimately resulting in a siege like scenario, making a diplomatic solution difficult. While there has been some recent headway towards a diplomatic solution, as some Iraqi politicians discuss the easing of sanctions against the northern regions (Al Masdar News, 2017), Lack of any real international support, including the UN, makes the scenario grim for Kurdish independence.

The third possibility is a formal secession of the northern Kurdish regions 
from Iraq, without any diplomatic overtures. Without diplomatic cards to play, a weakening economic situation and a large military force, a quick secession followed by fortifying borders would be the only real move for Kurdistan if independence is desperately sought. However, this is the most unlikely scenario. KRG have repeated they seek unconditional dialogue with the Iraqi federal government, and the risk of economic disaster is simply too great to cut ties without further communication. Even with Iraqi forces moving in on Kurdish territory, it is highly unlikely the Kurds will declare independence, and will likely seek to project a pacifist image to garner international support.

\section{Conclusion}

This paper demonstrates that the Kurdish position is quite weak. Without substantial diplomatic or economic capital, a separate Kurdistan is unlikely to happen without military commitment. However, following an examination of national sentiment and history, Kurdistan is unlikely to back down without some form of victory. The large majority of people in the Kurdistan region seek independence, and the future holds an increasingly unstable situation without dialogue between northern and southern Iraq. Kurdistan is playing an interesting game; Peshmerga withdrawals allowed Iraqi forces to take areas in Kirkuk and international sentiment has swung towards displaced civilians and Kurds, as reports of looting by Iraqi forces come to light. However, the Kurdish position is still weak, and without substantial diplomatic and regional support, a separate Kurdistan is unlikely to exist any time soon. Finally, as stated at the beginning of this paper, the Kurdistan separatist issue reveals more of the situation in the Middle East than a drive for independence. The bloc of states supporting the Iraqi federal government, Turkey and Iran, shows a new dynamic in the Middle East that moves beyond the Kurdistan issue. The US, perhaps seeing this new development, seeks to appease Iraq, rather than drive it towards an Iranian alliance, a cause that may well be too little too late. The new dynamic that is emerging here in the Middle East may well shift the future of international relations and security in the region, and is worth careful analysis in the future.

\section{References}

$\mathrm{Al}$ Ghad (2017). Minister of Industry Invites Iranian Companies to Visit Iraq. https://www.alghadpress.com/news/110418/AlghadPress-Article

Al Jazeera (2017). Iraq Refuses Talks with Kurds about Referendum Results. http://www.aljazeera.com/news/2017/09/iraq-refuses-talks-kurds-referendum-results-1 70926033646791.html

Al Masdar News (2017). Erbil, Baghdad Agree on Lifting Anti-Kurdish Sanctions. https://www.almasdarnews.com/article/erbil-baghdad-agree-lifting-anti-kurdish-sancti ons/

Berman, L. (2017). The Status of Western Military Aid to Kurdish Peshmerga Forces. Jerusalem Center for Public Affairs.

http://jcpa.org/article/the-status-of-western-military-aid-to-kurdish-peshmerga-forces/

Detsch, J. (2017). Pentagon Stops Paying Peshmerga Salaries amid Kurdish Independence 
Backlash. Al-Monitor.

http://www.al-monitor.com/pulse/originals/2017/10/pentagon-stop-paying-peshmerga -salaries-iraq-kurdistan.html

Dolamari, M. (2017). Iran Shuts down Kurdistan 24 Bureau in Tehran Following Kurdistan Referendum. Kurdistan 24.

http://www.kurdistan24.net/en/news/d4525fdc-5b02-4140-a03c-7e0ff4970bf0

Francis, B., \& Al-Tamimi, M. (2017). Kurds Reject Maliki's Demand for Control of Peshmerga Militia. Al-Monitor.

http://www.al-monitor.com/pulse/en/politics/2012/10/kurds-reject-malikis-demand-to -control-pesherga-militia.html

Gordon, M. R. (2017). Mattis Asks Iraqi Kurds to Put Off Vote on Independence. New York Times.

https://www.nytimes.com/2017/08/22/world/middleeast/iraq-kurds-independence-mat tis-barzani-tillerson.html

Heller, J. (2017). Israel Endorses Independent Kurdish State. Reuters. https://www.reuters.com/article/us-mideast-crisis-kurds-israel/israel-endorses-indepen dent-kurdish-state-idUSKCN1BO0QZ

Howard, M. (2017). The Struggle for Iraq's Oil Flares up as Kurds Open Doors to Foreign Investors. The Guardian.

https://www.theguardian.com/business/2007/aug/07/iraq.oilandpetrol

HRI (2017). Treaty of Lausanne. http://www.hri.org/docs/lausanne/

Javanmardi, A. (2017). Kurdish Independence and Its Implications for National Interests of United States. EKurd.

http://ekurd.net/kurdish-independences-implications-2017-09-19

KRG (2017). Mining. http://mnr.krg.org/index.php/en/mining

Lee, J. (2017). Baghdad Suspends Int'l Flights to Erbil. Iraqi Business News.

http://www.iraq-businessnews.com/2017/09/28/baghdad-suspends-intl-flights-to-erbil/

Litovkin, N. (2017). Russia Delivers First Weapons Supplies to Iraqi Kurds. Russia Beyond.

https://www.rbth.com/defence/2016/03/18/russia-delivers-first-weapons-supplies-to-ir aqi-kurds_576809

Lynch, H. (2017) When It Comes to Kurdistan's Water, Problems Flow but Not Solutions. Rudaw. http://www.rudaw.net/english/kurdistan/250720175

Middle East Online (2017). Iran Slaps Fuel Embargo on Iraqi Kurds. Middle East Online. http://www.middle-east-online.com/english/?id=85133

Mostafa, N. (2017). Peshmerga Kills Army, Paramilitary Personnel, West of Nineveh: Commander. Iraqi News.

https://www.iraqinews.com/iraq-war/peshmerga-kills-army-paramilitary-personnel-we st-nineveh-commander/

Muñoz, C. (2017). Iraqi Forces Retake Oil-Rich Kirkuk from Kurdish Control after Independence Referendum. The Washington Post.

https://www.washingtontimes.com/news/2017/oct/16/iraqi-forces-retake-kirkuk-kurdi sh-control/

Razzak, S. A. (2017). Ankara Proposes an Alternative Border Gate to Baghdad. Asharq Al Awsat.

https://english.aawsat.com/said/news-middle-east/ankara-proposes-alternative-bordergate-baghdad

Renaud, G. H. (2017). UN Denounces Violence in Tuz Khurmatu as Abadi Sends in 
Army to Restore Order. Kurdistan 24.

http://www.kurdistan24.net/en/news/ebab3f83-f80d-48bc-aaa9-493e878cd2eb

Reuters (2017). Iran and Iraq Sign Accord to Boost Military Cooperation. https://www.reuters.com/article/us-iran-iraq-military-idUSKBN1A80HJ

Rudaw (2017a). 92.73\% “Yes” for Independence: Preliminary Official Results. http://www.rudaw.net/english/kurdistan/270920174

Rudaw (2017b). Erdogan: Iraq, Iran, Turkey to Decide Together on Shutting down Kurdistan's Oil. http://www.rudaw.net/english/kurdistan/051020172

Rudaw (2017c). Erdogan: Turkey Will Take Measures against Kurdistan after "illegitimate" Vote. http://www.rudaw.net/english/middleeast/turkey/280920171

Rudaw (2017d). Iraqi Military Coordinating with Turkey, Iran to Control KRG Borders. http://www.rudaw.net/english/kurdistan/290920178

Rudaw (2017e). Kurdistan Shiite Leader Warns of Civil War If Referendum Proceeds. http://www.rudaw.net/english/kurdistan/140920174

Rudaw (2017f). Over 150,000 Enlisted as Peshmerga Troops in Kurdistan Region, Official Data Shows. http://www.rudaw.net/english/kurdistan/03042017

Rudaw (2017g). Reports: Hashd Al-Shaabi Withdraws from Disputed Areas. http://www.rudaw.net/english/kurdistan/19102017

Rutgers (2017). Al-Anfal and the Genocide of Iraqi Kurds, 1988. https://www.ncas.rutgers.edu/center-study-genocide-conflict-resolution-and-human-ri ghts/al-anfal-and-genocide-iraqi-kurds-1988

Tasnim News Agency (2017). Iraq Officially Asks Turkey, Iran to Deal Exclusively with Baghdad.

https://www.tasnimnews.com/en/news/2017/10/07/1538547/iraq-officially-asks-turkey -iran-to-deal-exclusively-with-baghdad

The Baghdad Post (2017). IRGC Mobilize Its Afghan Militias in Kirkuk. http://www.thebaghdadpost.com/en/story/18484/IRGC-mobilize-its-Afghan-militias-i n-Kirkuk 